\title{
Implementasi Model Inkuiri Terbimbing Berbantuan Pop-up book untuk Meningkatkan Kemampuan Berpikir Kreatif Peserta Didik
}

\author{
Ruqoyyah, M. Aji Fatkhurrohman, Yuni Arfiani
}

(C) 2020 JEMS (Jurnal Edukasi Matematika dan Sains)

This is an open access article under the CC-BY-SA license (https://creativecommons.org/licenses/bysa/4.0/) ISSN 2337-9049 (print), ISSN 2502-4671 (online)

\begin{abstract}
Abstrak:
Tujuan penelitian ini adalah mengetahui perbedaan dan pengaruh serta mengetahui keefektifan penggunaan model inkuiri terbimbing berbantuan pop-up book untuk meningkatkan kemampuan berpikir kreatif perserta didik. Pengambilan data yang diambil dengan teknis tes, lembar observasi, dan angket. Teknik analisis data yang digunakan yaitu uji t-test. Hasil penelitian menunjukan bahwa, terdapat perbedaan dan pengaruh hasil belajar kelas kontrol dan kelas eksperimen pada pembelajaran yang menggunakan model inkuiri terbimbing berbantuan pop-up book dilihat dari hasil kemampuan awal dan kemampuan akhir peserta didik. Penelitian ini juga mengukur keefektifan model ikuiri terbimbing berbantuan pop-up book untuk meningkatkan kemampuan berpikir kreatif peserta didik. Hasil analisis pada kelas eksperimen menggunakan NGain memperoleh rata- rata nilai sebesar 56,24 lebih besar dari kelas kontrol yang memperoleh rata-rata sebesar 45,1. Hal ini menunjukan bahwa pembelajaran IPA lebih efektif menggunakan model inkuiri terbimbing berbantuan pop-up book daripada hanya menggunakan model inkuiri terbimbing.
\end{abstract}

Kata Kunci: Inkuiri Terbimbing, Pop-up book, Berpikir Kreatif, Peserta Didik

\section{Pendahuluan}

Dalam UU No 20 Tahun 2003 menjelaskan bahwa Pembelajaran merupakan tahapan interaksi peserta didik dengan pendidik dan sumber belajar dalam lingkup lingkungan belajar.

Ruqoyyah, Universitas Pancasakti Tegal

oiyahisoyah@gmail.com

M. Aji Fatkhurrohman, Universitas Pancasakti Tegal ajifatkhur@upstegal.ac.id

Yuni Arfiani, Universitas Pancasakti Tegal

yuniarfiani@upstegal.ac.id

\begin{abstract}
:
The purpose of this study is to determine the differences and effects and to determine the effectiveness of the use of guided inquiry models assisted by pop-up books to improve students' creative thinking abilities. Retrieval of data taken with technical tests, observation sheets, and questionnaires. The data analysis technique used is the t-test. The results showed that, there were differences and the influence of the learning outcomes of the control class and the experimental class on learning using the guided inquiry model aided by pop-up books viewed from the results of the students' initial and final abilities. This study also measures the effectiveness of the guided inquiry model assisted by pop-up books to improve students' creative thinking abilities. The results of the analysis in the experimental class using N-Gain obtained an average value of 56.24 greater than the control class which obtained an average of 45.1. This shows that science learning is more effective using the guided inquiry model assisted by pop-up books than only using the guided inquiry model.
\end{abstract}

Keywords: Guided Inquiry, Pop-up book, Creative Thinking, Students 
Lingkungan belajar adalah daerah atau wilayah dengan semua isinya yang berkaitan dengan kegiatan belajar peserta didik. Lingkungan belajar meliputi lingkungan belajar di kelas (indoor) dan lingkungan belajar outdoor. Luasnya lingkungan belajar menjadi salah satu faktor yang mempengaruhi proses pembelajaran khususnya pembelajaran IPA. Pembelajaran IPA dikatakan baik yaitu sesuai Kurikulum Tingkat Satuan Pendidikan tidak cukup hanya bersumber pada buku saja, tapi juga pengajaran dilengkapi dengan media serta di hubungkan dengan lingkungan sekitar (Widiyatmoko \& Pamelasari, 2012).

Proses pembelajaran IPA akan bermakna ketika proses pembelajaran telah dimengerti dan dipahami oleh peserta didik. Pemahaman peserta didik terhadap konsep - konsep IPA, fenomena dan peristiwa alam dapat diamati melalui suatu proses penelitian atau percobaan. Dengan pemahaman terhadap fenomena alam, peserta didik dapat meningkatkan proses berfikir yang akan mempengaruhi hasil belajar peserta didik.

Dalam meningkatkan proses pembelajaran IPA terdapat point penting yang harus dipenuhi antara lain: (1) konsep yang akan dikelola pendidik agar bermakna, (2) kesiapan peserta didik dalam mengolah dan menerapkan informasi, (3) penataan lingkungan dalam konteks pelaksaan pembelajaran IPA (Wisudawati \& Sulistyowati, 2014). Model inkuiri terbimbing merupakan salah satu alternatif model pembelajaran yang dapat diterapkan dalam proses pembelajaran. Inkuiri terbimbing merupakan salah satu model yang efektif untuk membuat suasana baru dalam proses pembelajaran di kelas (Ambarsari \& Santosa, 2013). Dalam pendekatan inkuiri peserta didik tidak hanya diberikan pengetahuan melainkan peserta didik dibimbing untuk membangun sendiri pengetahuan dalam benaknya (Sutikno \& Isa, 2010). Selain itu, model yang dikolaborasikan dengan Pembelajaran berorientasi proyek menyediakan bidang yang luas untuk pembentukan pemikiran kreatif dan kreativitas (baik oleh peserta didik dan pendidik) (Tanggaard, 2011).

Penggunaan media pembelajaran dapat mendukung proses pembelajaran, mempermudah peserta didik dalam memahami materi pembelajaran, serta meningkatkan kualitas mengajar guru yang akan berdampak pada kualitas hasil belajar siswa (Kharisma, 2017). Kenyataannya penggunaan model pembelajaran inkuiri terbimbing belum digunakan secara maksimal (Ukhtinasari \& Mosik, 2017). Melalui penerapan media pop-up book yang cukup menarik, peserta didik diharapkan dapat meningkatkan kemampuan berpikir kreatif untuk memecahkan suatu masalah. Selain itu, media pop-up book dapat membangkitkan suasana belajar yang menyenangkan (Rahayu, 2017). Pada penelitian menunjukan bahwa hasil pencapaian peserta didik dengan nilai rata - rata diatas KKM yakni 95,3 (Khoiriyah \& Sari, 2018). Oleh karena itu, media pop-up book perlu digunakan dalam peningkatan proses pembelajaran keterampilan berpikir kratif peserta didik.

Pembelajaran yang bertujuan meningkatkan keterampilan berpikir kreatif perlu diterapkan dalam setiap proses pembelajaran, khususnya pembelajaran IPA. Hal tersebut disebabkan kreativitas adalah salah satu hal yang penting untuk kemajuan umat manusia (Kuo, Yeh, \& Allen, 2016). Kreativitas peserta didik dan pendidik juga merupakan salah satu faktor yang penting dalam proses pembelajaran (Fatmawati, 2016).

Penelitian ini bertujuan mengetahui perbedaan hasil belajar IPA antara kelas yang menggunakan model inkuiri terbimbing berbantuan media pop-up book dengan kelas yang tidak menggunakan media pop-up book. Mengetahui pengaruh implementasi model inkuiri terbimbing berbantuan pop-up book pada pembelajaran IPA dalam meningkatkan kemampuan berpikir kreatif peserta didik. Serta Mengukur keefektifan penggunaan model inkuiri terbimbing berbantuan pop-up book pada pembelajaran IPA. 


\section{Metode}

Penelitian ini merupakan penelitian eksperimen dengan desain penelitian quasi eksperimental dengan desain penelitian The non-equivalent groups design. Data yang digunakan adalah data kuantitatif. Teknik pengambilan data dengan menggunakan tes untuk mengetahui hasil belajar peserta didik, lembar observasi yang dikembangkan dari indikator berpikir kreatif untuk memperoleh informasi pengaruh implementasi model inkuiri terbimbing berbantuan popup book pada pembelajaran IPA dalam meningkatkan kemampuan berpikir kreatif peserta didik, dan angket untuk melihat minat belajar peserta didik.

Penentuan sampel penelitian ini, dilakukan dengan menggunakan teknik purposive sampling. Sampel yang diperoleh adalah yaitu kelas VIII A sebagai kelas eksperimen dan kelas VIII C sebagai kelas kontrol. Analisis data pada penelitian ini menggunakan uji normalitas yang bertujuan untuk memastikan bahwa data yang diperoleh normal atau tidak. Uji homogenitas untuk mengetahui kedua kelas memiliki varian yang sama (homogen) atau berbeda (heterogen). Uji Independent T-Test digunakan untuk menguji kebenaran hipotesis pertama yaitu terdapat perbedaan hasil belajar IPA antara kelas yang menggunakan model inkuiri terbimbing berbantuan pop-up book dengan kelas yang menggunakan model inkuiri terbimbing tanpa berbantuan pop-up book. Uji Paired Sample T-Test digunakan untuk melihat perbedaan skor sebelum dan sesudah dikenai perlakuan antara kelas eksperimen dan kelas kontrol. Serta N-Gain digunakan untuk menguji efektifitas model pembelajaran.

\section{Hasil dan Pembahasan}

Penelitian ini menggunakan 3 instrumen yaitu instrumen tes, lembar observasi, dan lembar angket. Instrumen tes digunakan untuk mengukur hasil belajar peserta didik ranah kognitif. Lembar observasi digunakan untuk mengukur kemampuan berpikir kreatif peserta didik yang memuat indikator rasa ingin tahu terhadap suatu masalah, kemampuan peserta didik dalam mengemukakan pendapat terhadap suatu masalah, kemampuan peserta didik mengerjakan soal latihan yang diberikan guru, kemampuan peserta didik dalam mengajukan pertanyaan, dan kemampuan peserta didik dalam menjawab pertanyaan. Lembar angket digunakan untuk mengukur minat peserta didik terhadap proses pembelajaran IPA.

Sebelum melakukan pembelajaran pada kelas eksperimen dan kelas kontrol, diberikan instrumen tes untuk mengukur kemampuan awal peserta didik sebagai data pre-test. Hasil dari pre-test dan post-test yang telah diambil dapat dilihat pada Tabel 1.

Tabel 1. Data Hasil Pre-test dan Post-test kelas eksperimen dan kelas kontrol

\begin{tabular}{ccccccc}
\hline Kelas & & N & Mean & Std. Deviation & Min & Max \\
\hline Eksperimen & Pre-test & 32 & 36,25 & 6,501 & 28 & 48 \\
& Post-test & 32 & 72,50 & 7,721 & 56 & 88 \\
Kontrol & Pre-test & 32 & 36,50 & 5,542 & 28 & 44 \\
& Post-test & 32 & 65,50 & 6,565 & 56 & 76 \\
\hline
\end{tabular}

Tabel 1. memperlihatkan bahwa hasil belajar pada kedua kelas terdapat peningkatan setelah melaksanakan pembelajaran. Hal ini ditunjukan pada perolehan rata-rata nilai pada kelas eksperimen dan kelas kontrol yaitu 72,50 dan 65,50.

Perbedaan pada kelas yang menggunakan model inkuiri terbimbing berbantuan pop-up book dengan kelas yang menggunakan model inkuiri terbimbing tanpa berbantuan pop-up book. Hasil uji independent sample t-test dapat dilihat pada Tabel 2. 
Tabel 2. Hasil Perhitungan Nilai Hasil Belajar dengan Uji Independent Sample T-Test

\begin{tabular}{lrrrrc}
\hline & F & Sig. & T & Df & Sig. (2-tailed) \\
\hline $\begin{array}{l}\text { Hasil belajar } \\
\text { IPA }\end{array}$ & .635 & .429 & 3.907 & 62 & .000 \\
\hline
\end{tabular}

Berdasarkan data pada Tabel 2 diketahui bahwa nilai sig. (2-tailed) pada kolom equal variances assumed sebesar 0,000 yang menunjukan nilai tersebut lebih kecil dari 0,05. Data tersebut menunjukan bahwa kedua kelas yaitu kelas eksperimen dan kelas kontrol memiliki perbedaan pada hasil belajar.

pengaruh pada kelas yang menggunakan model inkuiri terbimbing berbantuan pop-up book dengan kelas yang menggunakan model inkuiri terbimbing tanpa berbantuan pop-up book diuji menggunakan uji paired sample t-test. Hasil uji paired sample t-test dapat dilihat pada Tabel 3.

Tabel 3. Hasil Analisis Perhitungan Hasil Belajar dengan Paired Sample T-Test

\begin{tabular}{llccc}
\hline & & $\mathrm{f}$ & $\mathrm{Df}$ & Sig. (2-tailed) \\
\hline Pair 1 & $\begin{array}{l}\text { pre-test kelas } \\
\text { eksperimen - post-test } \\
\text { kelas eksperimen }\end{array}$ & -19.249 & 31 & .000 \\
\hline Pair 2 & $\begin{array}{l}\text { pre-test kelas kontrol - } \\
\text { post-test kelas kontrol }\end{array}$ & -17.617 & 31 & .000 \\
\hline
\end{tabular}

Berdasarkan data pada Tabel 3. diketahui bahwa nilai sig. (2-tailed) pada pair 1 sebesar 0,000 yang menunjukan nilai tersebut lebih kecil dari 0,05 atau Ha di terima. Dengan kata lain bahwa terdapat pengaruh model inkuiri terbimbing berbantuan pop-up book pada pembelajaran IPA. Hasil perhitungan N-Gain pada kelas eksperimen yang menggunakan model inkuiri terbimbing berbantuan pop-up book dan kelas kontrol yang menggunakan model inkuiri terbimbing tanpa berbantuan pop-up book dapat dilihat pada Tabel 4.

\begin{tabular}{ccc}
\multicolumn{3}{c}{ Tabel 4. Perhitungan Rata-Rata N-Gain Kelas Eksperimen dan Kelas Kontrol } \\
\hline \multirow{2}{*}{ Ukuran } & \multicolumn{2}{c}{ Nilai } \\
\cline { 2 - 3 } & Kelas eksperimen & Kelas kontrol \\
\hline Mean & 56,24 & 45,1 \\
Median & 55,90 & 45,20 \\
Maximum & 83,33 & 64,71 \\
Minimum & 15,38 & 21,43 \\
Std. Deviasi & 13,99 & 12,32 \\
\hline
\end{tabular}

Berdasarkan Tabel 4 menunjukan bahwa kelas yang menggunakan model inkuiri terbimbing berbantuan pop-up book memiliki rata-rata sebesar 56,24 berada pada kriteria cukup efektif. Sedangkan, Rata-rata dari kelas kontrol adalah 45,1 yang menunjukan bahwa model inkuiri terbimbing kurang efektif digunakan dalam proses pembelajaran. Hal ini membuktikan bahwa menggunakan model inkuiri terbimbing berbantuan pop-up book lebih efektif daripada hanya menggunakan model inkuiri terbimbing.

Penilaian kemampuan berpikir kreatif dilakukan ketika peserta didik berkelompok. Hasil observasi kelas eksperimen dan kelas kontrol dapat dilihat pada Tabel 5. 
Tabel 5. Hasil Observasi Kemampuan Berpikir Kreatif kelas eksperimen dan kelas kontrol

\begin{tabular}{ccc}
\hline \multirow{2}{*}{ KODE } & \multicolumn{2}{c}{ Skor } \\
\cline { 2 - 3 } & Kelas eksperimen & Kelas kontrol \\
\hline KK1 & 52 & 46 \\
\hline KK2 & 50 & 46 \\
\hline KK3 & 50 & 49 \\
\hline KK4 & 54 & 47 \\
\hline KK5 & 51 & 46 \\
\hline RATA-RATA & 51,4 & 46,8 \\
\hline MEDIAN & 51 & 46 \\
\hline MODUS & 50 & 46 \\
\hline MINIMUN & 50 & 46 \\
\hline MAXIMUM & 54 & 49 \\
\hline STD. DEVIASI & 1,673320053 & 78 \\
\hline PERSENTASE $(\%)$ & 85,67 &
\end{tabular}

Tabel 5 menunjukan bahwa kemampuan berpikir kreatif kelas eksperimen lebih baik dibandingkan dengan kelas kontrol. Pada kelas eksperimen diperoleh nilai rata-rata yaitu 51,4 lebih besar dibanding nilai rata-rata yang diperoleh kelas kontrol yaitu 46,8. Dalam tafsiran persentase menunjukan kelas eksperimen memperoleh 85,67 \% berada pada kriteria sangat tinggi dan kelas kontrol memperoleh $78 \%$ berada pada kriteria tinggi. Hasil lembar angket yang diperoleh pada proses pembelajaran dapat dilihat pada Tabel 6.

Tabel 6. Hasil Angket Respon Peserta Didik

\begin{tabular}{ccc}
\hline \multirow{2}{*}{ Ukuran } & \multicolumn{2}{c}{ Nilai } \\
\cline { 2 - 3 } & Kelas eksperimen & Kelas kontrol \\
\hline Mean & 50,38 & 31,5 \\
Median & 49 & 34 \\
Modus & 49 & 28 \\
Maximum & 60 & 32 \\
Minimum & 47 & 32 \\
Std. Deviasi & 3,30 & 1,54 \\
\hline
\end{tabular}

Berdasarkan Tabel 6 menunjukan adanya perbedsan pada kelas eksperimen memperoleh nilai 50,38 dan kelas kontrol memperoleh nilai 31,5. Hal ini menunjukan bahwa pada kelas yang menggunakan model inkuiri terbimbing berbantuan pop-up book lebih berminat terhadap pembelajaran saat berlangsung dibanding dengan kelas yang menggunakan model inkuiri terbimbing.

Proses pembelajaran berlangsung ketika telah diperoleh data untuk mengukur kemampuan awal peserta didik. Kemampuan awal peserta didik diukur menggunakan soal yang telah valid sebelumnya. Dari hasil yang diperoleh kedua kelas memiliki kemampuan awal yang rendah. Hal ini akan menunjukan bahwa kelas eksprimen dan kelas kontrol memiliki kemampuan awal yang sama.

Berdasarkan hasil penelitian menunjukan terdapat perbedaan antara kelas yang menggunakan model ikuiri terbimbing berbantuan pop-up book dengan kelas yang hanya 
menggunakan model ikuiri terbimbing. Selain itu, hasil penelitian ini juga menunjukan terdapat pengaruh antara kelas eksperimen dengan kelas kontrol. Hal ini mengacu pada perolehan nilai ataupun penilaian yang telah dilakukan selama pembelajaran berlangsung. Dalam penelitian ini juga menunjukan bahwa menggunakan model inkuiri terbimbing berbantuan pop-up book pada pembelajaran IPA lebih efektif daripada menggunakan model inkuiri terbimbing.

Hasil analisis menunjukan bahwa antara kelas eksperimen dan kelas kontrol terdapat perbedaan. Uji hipotesis pertama menggunakan uji independent sample $t$ test dengan taraf signifikan $5 \%$ di peroleh $a=0,000$. Dari hasil uji tersebut menunjukan bahwa $\alpha<0,05$ yang artinya terdapat perbedaan antara kelas yang menggunakan model inkuiri terbimbing berbantuan popup book dengan kelas yang menggunakan model inkuiri terbimbing.

Pengujian hipotesis kedua juga menyatakan bahwa terdapat pengaruh model inkuiri terbimbing berbantuan pop-up book antara kemampuan awal dan kemampuan akhir pada kelas eksperimen dan kelas kontrol. Hal ini ditunjukan pada hasil analisis kemampuan akhir yang mengalami peningkatan. Selain itu, hasil uji yang menggunakan uji paired sample $t$ test dengan taraf signifikan $5 \%$ yang memperoleh hasil $a=0,000$. Hal ini berarti bahwa $\alpha<0,05$ yang artinya terdapat pengaruh hasil belajar antara kelas eksperimen dan kelas kontrol.

Model inkuiri terbimbing berbantuan pop-up book mempengaruhi berpikir kreatif dan minat peserta didik. Pasalnya pada kelas eksperimen peserta didik lebih aktif berpartisipasi dalam pembelajaran dan lebih aktif dalam bertanya serta saling membantu teman satu sama lain jika terdapat kesulitan dalam menjawab pertanyaan. Hasil observasi kemampuan berpikir kreatif peserta didik yang telah dilakukan menunjukan bahwa persentase kelas eksperimen sebesar $85,67 \%$ lebih besar dibanding persentase kelas kontrol yaitu $78 \%$. Dengan persentase tersebut kemampuan berpikir kreatif peserta didik kelas eksperimen berada pada kriteria "Sangat Tinggi" dan kelas kontrol berada di kriteria "Tinggi".

Dari hasil analisis lembar observasi, kelas eksperimen berada pada kriteria sangat tinggi dan kelas kontrol berada pada kriteria tinggi. Hal ini disebabkan bahwa pada kelas eksperimen dan kelas kontrol memiliki kesempatan yang sama untuk menjawab pertanyaan ataupun kesempatan berdiskusi. Pada kelas kontrol terdapat kelompok yang memiliki nilai tinggi sehingga dapat mempengaruhi perolehan skor seluruh kelompok.

Dalam proses pembelajaran juga diukur minat atau ketertarikan perserta didik menggunakan instrumen lembar angket yang diisi oleh peserta didik setelah proses pembelajaran selesai. Analisis lembar angket yang telah dilakukan memperoleh rata-rata pada kelas eksperimen yaitu 50,38 dan pada kelas kontrol 31,5. Hasil yang diperoleh Hasil analisis tersebut menunjukan bahwa ketertarikan peserta didik pada kelas yang menggunakan model ikuiri terbimbing lebih baik daripada kelas yang menggunakan model inkuiri terbimbing.

\section{Simpulan}

Penerapan model inkuiri terbimbing berbantuan pop-up book pada peserta didik kelas VIII menunjukan Terdapat perbedaan hasil belajar IPA antara kelas yang menggunakan model inkuiri terbimbing berbantuan media pop-up book dengan kelas yang tidak menggunakan media pop-up book dan Terdapat pengaruh implemetasi model inkuiri terbimbing berbantuan pop-up book pada pembelajaran IPA dalam meningkatkan kemampuan berpikir kreatif peserta didik di kelas VIII semester I. Serta Model inkuiri terbimbing berbantuan pop-up book lebih efektif dalam meningkatkan kemampuan berpikir kreatif dibandingkan dengan model inkuiri terbimbing. 
Bedasarkan simpulan diatas, maka penulis memberikan saran pada saat proses pembelajaran dilakukan secara berkelompok dapat menambahkan kegiatan tambahan berupa tebak-tebakan ataupun permainan ketika proses belajar berlangsung serta model inkuiri terbimbing berbantuan pop-up book dapat dijadikan salah satu alternatif dalam pembelajaran IPA pada materi struktur dan fungsi jaringan tumbuhan.

\section{Daftar Rujukan}

Ambarsari, W., \& Santosa, S. (2013). Terhadap Keterampilan Proses Sains Dasar Pada Pelajaran Biologi Siswa Kelas Viii Smp Negeri 7 Surakarta. Jurnal Pendidikan Biologi, 5, 81-95.

Fatmawati, B. (2016). The Analysis of Students ' Creative Thinking Ability using Mind Map in Biotechnology Course. Jurnal Pendidikan IPA Indonesia, 5(2), 216-221.

Kharisma, M. (2017). Pengembangan Media Pembelajaran Pop-up untuk Meningkatkan Hasil Belajar dan Petrokimia di Kelas XI Mas Muta' Allimin Aceh Besar. Zigma, 13-18.

Khoiriyah, E., \& Sari, E. Y. (2018). Pengembangan Media Pembelajaran Pop-up Book pada Mata Ppelajaran IPA Kelas III SDN 3 Junjung Kecamatan Sumbergempol Kabupaten Tulungagung Tahun Ajaran 2017/2018. Jurnal Bidang Pendidikan Dasar, 2(2), 22-32.

Kuo, C., Yeh, Y., \& Allen, A. P. (2016). Sensorimotor-Conceptual Integration in Free Walking Enhances Divergent Thinking for Young and Older Adults. Frontiers in Psychology, 7, 1-9.

Rahayu, P. G. (2017). Pengembangan Media Pembelajaran Pop-up Lingkungan Sekitar Siswa Kelas IV SDN Petok Mojo. Simki-Pedagogia, 01(03).

Sutikno, W., \& Isa, A. (2010). Keefektifan pembelajaran berbantuan multimedia menggunakan metode inkuiri terbimbing untuk meningkatkan minat dan pemahaman siswa. Jurnal Pendidikan Fisika Indonesia, 6, 58-62.

Tanggaard, L. (2011). Stories About Creative Teaching and Productive Learning. European Journal of Teacher Education, 34:2, 219-232.

Ukhtinasari, F., \& Mosik, S. (2017). Pop-up sebagai Media Pembelajaran Fisika Materi Alat-Alat Optik untuk Siswa Sekolah Menengah Atas. Unnes Physics Education Journal, 6(2).

Widiyatmoko, a., \& Pamelasari, S. D. (2012). Pembelajaran berbasis proyek untuk mengembangkan ALAT peraga IPA dengan memanfaatkan bahan bekas pakai. Jurnal Pendidikan IPA Indonesia, 1(1), 51-56.

Wisudawati, A. W., \& Sulistyowati, E. (2014). Metodologi pembelajaran IPA. Jakarta: Bumi Aksara. 